\title{
CORE COMPETENCE-BASED DIFFERENTIATION STRATEGY: CREATING COMPETITIVE ADVANTAGE
}

\author{
Isa IPCIOGLU \\ Gurhan UYSAL \\ Dumlupınar University, Turkey
}

\begin{abstract}
This study aims to identify core competencies of Turkish firms that create differentiation, that leading to competitive advantage. We asked the firms what their competencies differentiate from their competitors, and how those competencies provide of competitive advantage in market. To have impact on competitive advantage, core competence should create customer value, and involve unique and firm-specific expertise, and can be applied to different areas. We applied the research on 50 large firms in Marmara Region of Turkey. The results show that Turkish firms effectively identify their core competencies that differentiate them in the market and believe in those competencies provide of competitive advantage such as being market and industry leader, customer choice, customer satisfaction and trust, high demand and quality products.
\end{abstract}

\section{INTRODUCTION}

Differentiation strategy is to create unique and different products and services. In today's business environment, several firms produce similar products or services. Why customers choose a firm's particular product or service. Differentiation affects customers' choice. Core competence of a firm provides of differentiating products or services. Therefore, being successful in demanding environment, firms should integrate their organizational processes with their strategic competencies that are not imitable because core competencies are firm-specific activities, and these activities differentiate firm from rivals. A firm can develop firm-specific activities through its accumulated knowledge, experience, and organizational system that contribute to developing new strategic assets. Core competencies have an impact on competitive advantage by helping a firm to develop organizationspecific expertise. Social and collective learning and utilization of organization-specific knowledge in value chain activities provide of generating organizational expertise that later, turns into implementing unique and inimitable operations and activities. This study, therefore, aims to identify core competence of Turkish firms that differentiate them in markets, and how those competencies can create competitive advantage for them.

\section{The Need of Core Competence for Competitive Advantage}

Corporate survival is in the long term dependent on the ability to exploit core competencies (Torkkeli, Tuominen, 2002: 282) because technology, learning and skills are specific to the context of their development and use within the firm, and competencies may have little or no market value to other firms (Lei et al., 1996: 551). Core competencies are irreversible investments that determine the future capabilities and strategic opportunities (Lei et al., 1996: 551). Technology is also key to success since the right technology can offer very effective leverage when a company builds its core competencies (Torkkeli, Tuominen, 2002: 271). Core competence is an entrepreneurial decision-ability to respond to the dynamics of the environment (Banerjee, 2003: 252). Firm-specific capabilities, skills and technologies allow a firm to rapidly catch opportunities in the market, and to constantly watch the changes in the business environment. For example Fujitsu, Honda, Sumitomo and NSK's competence-based missions allow them to obtain achievements and to see opportunities arising in the business (Carr, 1997: 55). Another example is HortResearch company, a New Zealand scientific research institute: With competition for research and development funding increasing, HortResearch experience shows that core competence strategy process helps senior management to link the portfolio of research projects with changing industry and sector priorities (Clark, Scott, 2000: 496). Core competencies are therefore currently viewed as 
the primary means to enable organizations to respond to their environments (Godbout, 2000: 78). HortResearch company successfully followed the core competence based strategy process throughoutdeveloping industry foresight, generating consensus and committing to an ambitious, future strategic intent, identifying core competencies to create this future (Clark, Scott, 2000: 505).

To reach success, core competencies should not be obsolete or irrelevant; conversely, they should be sustained and improved (Torkkeli, Tuominen, 2002: 275 ) to develop a unique and effective product/market policy (Godbout, 2000: 78). For example, Fujitsu saw their core competence in terms of complementary technologies, which could be directed into a number of market areas such as multi-media, telecommunications, semiconductors, as well as mainframe and personal computers (Carr, 1997: 54). That example shows that the competitiveness of companies derives from an ability to build the core competences that will result in new business development more speedily than others (Möllersten, Sandberg, 2004: 81). The new business development competence seems to have a marketing orientation, and seems to emphasize a focus on the customer as a source of competitive advantage (Wright et al., 1998: 21). A core competence process for new business development programmes should begin internally interviewing individuals, and then, after interview, the potential core competencies are evaluated with customers, suppliers, and industry experts (Clark, 2000: 116).

Building new core competencies helps the firm to penetrate into emerging markets by developing new products that fit to challenges and demands of these markets. They form products in which intra- and interorganizational business strategies, innovative processes, logistics and individual competencies find their expression (Godbout, 2000: 78). Therefore, a new product can satisfy customer quality with the requirement specification (Osterlund, 2001: 161). In addition, product innovation contributes to the competitiveness of the firm through its dynamic and reciprocal relation with the firm's competences (Danneels, 2002: 1095).

Company's major brands will be successfully introduced to market as long as they are manufactured efficiently. Core competence efficiently produces the firm's products and makes good business based upon them (Möllersten, Sandberg, 2004: 84). It is the base for making competitive products (Osterlund, 2001: 160 ) by anticipating customer needs and leveraging resources to provide unique value to customers (Clark, 2000: 116). Textile executives say, their competencies are understanding the needs of end users of their products, and flexible manufacturing through quick changeovers (King, Zeithaml, 2001: 82). Moreover, new products are created by linking competences relating to technologies and customers (Danneels, 2002: 1095). Without knowledge and know-how, organizations become dependent on suppliers and external technology and fail to control the key resources of their sustainability (Godbout, 2000: 78). The only way to earn above-normal economic returns is to forecast the future value of resources to the firm more accurately than competitors (Makadok, Walker, 2000: 855). Core competence development should include customer needs to support them in their business operations. For example, in Sweden, an executive manager of a pulp producer emphasized the importance of giving support to the customer so that the customer's paper machines work properly (Möllersten, Sandberg, 2004: 86). This support will attract new customers toward the company, and hold existing buyers.

Attracting new consumers requires new competencies and organizational renewal to meet the customer demands and to survive in a business environment. An executive manager emphasizes to know customer needs to build a completely new competence in marketing and sales (Möllersten, Sandberg, 2004: 87). New competencies are the knowledge for product innovation that has been recognized as a primary means of corporate renewal that involves the building and expansion of organizational competencies over time (Danneels, 2002: 1095). Therefore, new products in the market will face high success. In other words, new products with a closer fit to firm competences tended to be more successful because competencies involve employee knowledge and skills, technical systems, administrative systems, values and norms (Danneels, 2002: 1096) and because competencies consist of the synergy of intellectual assets such as motivation, employee effort, technological and professional expertise, and methods of collaboration and management processes (Godbout, 2000: 78). A corporate focus on core competencies builds synergy between units and provides the rationale for resource allocation and investment (Clark, 2000: 121).

Strategy making focuses on the firm's heterogeneous resources, capabilities and competencies as those provide a more stable basis for competitive positioning in a turbulent environment (Clark, 2000: 116). Because competencies produce high-quality products that add value to consumers. According to Douglas and Ryman study (2003), the value of a hospital's strategic 
competencies is positively related to hospital financial performance. Pehrsson (2004) also found the same result that high strategy competence is generally associated with high performance of the entrant business. The way in which competencies are mustered will be a primary factor in determining the degree of difference between average and superior performance (Godbout, 2000: 83). Because it provides a new way of thinking about future priorities and positioning, which are the factors critical for successful core competence strategy implementation (Clarl, Scott, 2000: 507). In the contemporary management literature, there is prevailing belief that organizations which learn to work systematically with their core competencies achieve considerable strategic power (Godbout, 2000: 78). It also develops an organization's capability in building shared vision, personal mastery, and system thinking that is to understand wholes, and to learn how the actions shape the strategy (Osterlund, 2001: 165). This requires organizational changes. The most successful changes and turnarounds in the Western industrial world are cases where organizations have concentrated on the core competencies of the organization and the quality of competencies of their employees (Godbout, 2000: 76). At the organizational level, core competence based strategy making will translate into changes- new products, new processes, new skills and new people (Clark, 2000: 123). For instance, HortResearch company culminates the transformation of their organization from a bureaucratic Government department to a commercially successful science business by the process of developing a new strategy based on core competencies (Clark, Scott, 2000: 496).

The core competence approach to strategy making is only one of many contributions within emerging resource based view of the firm, and arrived at a time when executives in large corporations were aware that many of the traditional approaches were inadequate, and it offered a compelling rationale for corporate strategy decisions, resource allocation and competition (Clark, 2000: 115). Moreover, a core competence helps an organization achieve its chosen competitive advantage by providing customer value, competitor differentiation, and extendibility to markets (Franklin, 1997: 373). Therefore, the acquisition and development of the right core competences to create future is clearly a strategic issue (Franklin, 1997: 374) because shaping future deals with positioning the firm in the industry (Douglas, Ryman, 2003: 333). Therefore, forecast the future is a specific competence that a firm should have (Makadok, Walker, 2000: 854). HortResearch Institute is successful in implementation of core competence strategy making by managing the three core elements of their business: Anticipating future needs, managing integrated research teams, and delivering innovative and effective solutions (Clark, Scott, 2000: 501). Makadok and Walker's study (2000) shows that superior forecasting ability generates an economic surplus, and that the stronger a firm's forecasting competence, the larger the firm will subsequently grow. Two key components of firm success are firm core competencies and industry structure; thus, a firm must develop competencies that allow it to successfully position itself within its industry (Douglas, Ryman, 2003: 333).

Any company that aims to obtain competitive edge should build causal ambiguity to save their core competencies. Executives emphasize that if a competitor could copy their information systems, which is their core competence, they would lose much of their competitive advantage (King, Zeithaml, 2001: 82). Causal ambiguity, which is ambiguity about the link between firm resources and sustained competitive advantage, protects resources from competitive imitation although socially complex resources such as a good reputation and trust are time-consuming and expensive to imitate (King, Zeithaml, 2001: 76). Causal ambiguity among competitors protects the firm because competitors cannot imitate valuable competencies if they do not understand the relationship between these resources and competitive advantage (King, Zeithaml, 2001: 76).

\section{From Core Competencies to Differentiation Strategy}

Firm's longevity in the market depends on utilization of their core competencies (Torkkeli, Tuominen, 2002) because core competence in value chain results in successful penetration of products to market (Gallon, Stillman, 1995).

Prahalad and Hamel (1990:83-84) propose three tests to identify core competences. A competence should provide potential access to a wide variety of markets, and make a significant contribution to the perceived customer benefits of the end product, and be tough for competitors to imitate. The examples of success stories of firms that successfully define and develop their core competencies are (Stalk et. al., 2000:180-182): After World War II, Honda was just a small motor manufacturer for bicycle. Today, Honda can compete with General Motors and Ford. Xerox innovated an electrostatic copy, and developed photocopy machines for office usage. But in between 1976 and 1983, Canon presented more than 90 new models to market, and decreased Xerox's market share by $50 \%$. Canon, today, is a major competitor not only in medium-size photocopy machine but also in color machine. Macy's competitive 
problems in the market do not come from other department stores or small firms but comes from The Limited Company. The Limited company has 5.25 billion dollar sales in design, supply, and retail, and can move fast in the market like small boutique stores, and therefore, has a large number of customers. Citicorp, in assets, is the biggest banking corporation in the US; but Banc One's market value is greater than Citicorp because Banc One has the greatest return in US banking industry.

Prahalad and Hamel say, firstly, that a core competence develops competitive advantage by creating new product and services. Secondly, core competence generates customer value. Thirdly, a core competence differentiates a firm from competitors. Customer value requires differentiation in market. Therefore, firms should use their core competencies to effectively differentiate themselves from competitors because basics of differentiation go back to core competence of a firm. For example, core competencies are made up of skills, organizational assets and organizational process (Williamson, 1999), and therefore, those firmspecific skills, organizational assets and process develop unique products and services. Thus, core competence of corporation increases competitive advantage, and moreover, provides of coordination of organizational activities. loyalty because firm's product or service is unique in the market (Porter, 2000: 47). In addition, it is expected from a differentiation strategy to be sustainable and valuable to customers (Thompson, Strickland, 1995:126). This customer value is essentially provided by the unique attributes and characteristics of a firm's product (Hitt, et al., 1997:123). That is, customer value is to provide customer of unique attributes and characteristics of product. A firm can upload those attributes and characteristics to products via its capabilities in value chain, i.e., via core competencies, because core competence produces unique products via its qualities in value chain such as firm-specific knowledge, skills, expertise, technology. This is important because customers have high interest and appeals to differentiated features in products; therefore, the stronger the buyer appeal of differentiated features, the stronger the company's competitive advantage (Thompson, Strickland, 1995:126). For example, a firm can differentiate its products or services in service, design and brand name (Fieldcrest in first class towel; Mercedes in automobile), technology (Hyster in forklift; Macintosh in streo parts; Coleman in camp equipments), specifications (Jenn-Air in electrical owen), customer service (Crown Cork and Seal in metal pans). The important matter in differentiation strategy is that a firm differentiates itself in several dimensions (Porter, 2000: 47). Differentiation can be

$$
\text { Core Competencies } \longrightarrow \text { Differentiation Strategy } \longrightarrow \text { Competitive Advantage }
$$

For instance, Wal-Mart is a world leader and one of the strongest firms in retailing. This strength comes from Wal-Mart's creation of competence-based business strategies. Wal-Mart's competencedevelopment began with investments in suitable payment conditions for suppliers, trucks that run effectively, satellite communication, company-owned planes, and video conferences. These investments improved communication between Wal-Mart and its suppliers. For instance, suppliers could easily reach Wal-Mart's sales data, and so, could reply the demands of Wal-Mart stores very fast. Moreover, distribution centers deliver new orders less than 48 hours. Store managers can share their best practices with others. These linked business processes provide Wal-Mart of competitive superiority (Stalk et al., 2000:180-182).

Differentiation set up link between core competence and competitive advantage because successful differentiation allows a firm to set premium prices for its products, to increase unit sales and to gain customer loyalty (Thompson, Strickland, 1995: 126). Furthermore, differentiation strategies provide cost management to companies, and results in customer obtained by developing new products and enhancing the existing products. Such project innovations can help companies to decrease costs and to improve customer satisfaction.

The figure below shows value-creating activities associated with the differentiation that links core competence to competitive advantage:

Figure 1 illustrates the examples of primary and support activities that are used commonly to differentiate a good or service. Value chains can be also utilized to determine whether the necessary activities of differentiation strategy implementation stage can be linked or not. Without linking those activities to the core competencies, a company cannot implement the differentiation strategy successfully (Hitt et. al., 1997:128).

\section{Research}

50 large firms in Marmara Region of Turkey from various sectors are explored in this study. They are listed in first 500 companies of Turkey by Istanbul Chambers of Industry and Capital Journal. Firms have been requested to answer what their core competencies 


\section{FIGURE 1: EXAMPLES OF VALUE-CREATINGACTIVITIES ASSOCIATED WITH THE DIFFERENTIATION BY MICHAEL E. PORTER}

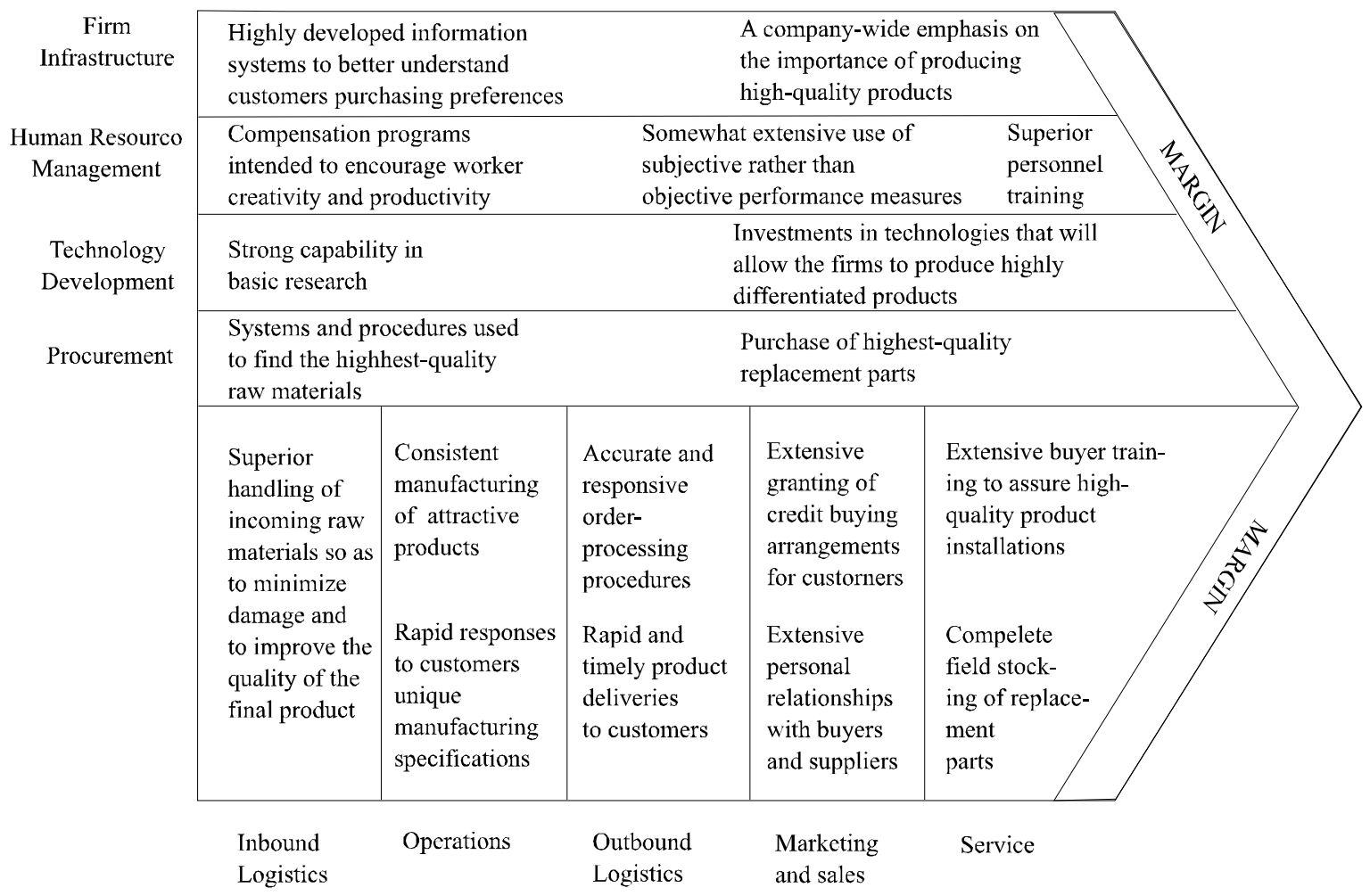

Source: Adapted from Hitt et. al., 1997:128.

differentiate them from their competitors, and if their core competencies provide them any significant competitive advantage. The questions were asked to upper and middle-level managers by e-mail and interview. The classified responses that are obtained from 37 firms are given in Table 1 below. Table 1 shows the sector types of firms, the core competencies of them differentiate them from their competitors, and competitive advantages that core competencies of firms provide. However, some firms did not provide any particular competitive advantage.

\section{The Core Competencies of Turkish Firms}

According to Coyne et. al. (1997:41-42) core competencies can be grouped in to two categories, which are Insight / Foresight competencies, and Frontline Execution competencies.

The competencies in the first group enable companies to discover facts that create first-mover advantages. These competencies can be derived from the followings (Coyne et. al., 1997, 41-41):
- Technical or scientific knowledge that produces a string of inventions

- Proprietary data

- Information derived from having the largest share of leading-edge transactions in the deal flow

- Pure creative flair in inventing successful products

- Superior analysis and inference

The competencies in the other group take place as the quality of a final good or service can vary appreciably according to the activities of frontline personnel. Although both competency groups can coexist in the same company, each requires its own managerial focus (Coyne et. al., 1997:42). Although the majority of Turkish firms' core competencies fall into these two groups, some firms' core competencies are general such as brand. Because while brand management is a core competence, brand is not a core competence (Kırım, 1998:44) 


\section{TABLE 1: THE CORE COMPETENCIES OF TURKISH FIRMS}

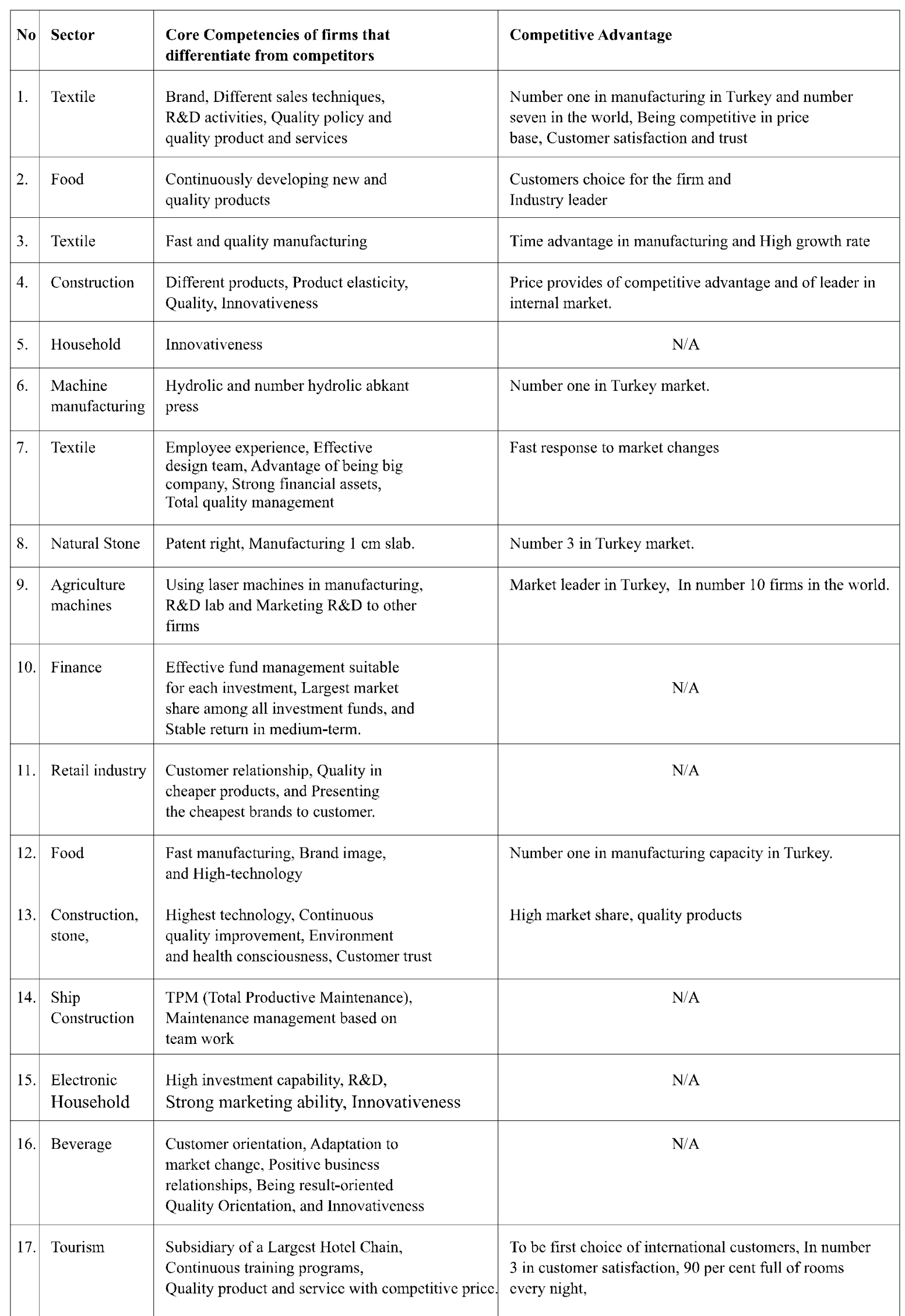




\begin{tabular}{|c|c|c|c|}
\hline 18. & Automotive & $\begin{array}{l}\text { Motor, Sales force management and } \\
\text { new product development management, } \\
\text { Elasticity and continuous development, } \\
\text { Giving importance to customer needs, } \\
\text { and Benchmarking }\end{array}$ & $\begin{array}{l}\text { Creating strategic value via its competencies, Creating } \\
\text { effectiveness and efficiency, Strategic success, and } \\
\text { higher profits than average. Motor competence of the } \\
\text { firm plays key role in differentiating the firm from rivals. }\end{array}$ \\
\hline 19. & Household & $\begin{array}{l}\text { Production and Product Quality, } \\
\text { Investment to have technological } \\
\text { superiority, Brand strategy, } \\
\text { Managerial elasticity for different } \\
\text { markets penetrated, } \\
\text { Strong distribution channel, } \\
\text { Effective and wide service provided, } \\
\text { Response ability to changing customer } \\
\text { expectations, Qualified manpower, and } \\
\text { Producing our own technology. }\end{array}$ & $\mathrm{N} / \mathrm{A}$ \\
\hline 20. & Machine & $\begin{array}{l}\text { Expertise and knowledge, } \\
\text { Product quality and image, and Design }\end{array}$ & $\begin{array}{l}\text { Industry leader, and competing with } \\
\text { world giants. }\end{array}$ \\
\hline 21. & Textile & $\begin{array}{l}\text { Performance-based pay, } \\
\text { Effective performance management, and } \\
\text { Evaluating employee ideas. }\end{array}$ & $\begin{array}{l}\text { High product quality, High demand for products. Those } \\
\text { results in competitive advantage over rivals. }\end{array}$ \\
\hline 22. & $\begin{array}{l}\text { Pipe } \\
\text { Manufac } \\
\text { turing }\end{array}$ & $\begin{array}{l}\mathrm{R} \& \mathrm{D} \text { activities, and Manufacturing } \\
\text { products with new technology. }\end{array}$ & $\begin{array}{l}\text { New market penetration. High technology production } \\
\text { leads to fast and efficient manufacturing that differentiates } \\
\text { firm from rivals. }\end{array}$ \\
\hline 25. & Textile & $\begin{array}{l}\text { Technology investment, Customer- } \\
\text { oriented quality manufacturing, and } \\
\text { R\&D }\end{array}$ & N/A \\
\hline 26. & Automotive & $\begin{array}{l}\text { EURO II patent motor that Same } \\
\text { tractors use, oil save, brake systems } \\
\text { that different from Same tractor }\end{array}$ & N/A \\
\hline 27. & Glass industry & $\begin{array}{l}\text { Economics of Scale, } \\
\text { High volume raw materials purchase }\end{array}$ & Bargaining power over suppliers \\
\hline 28. & Textile & $\begin{array}{l}\text { Electronic and computer-aided } \\
\text { manufacturing }\end{array}$ & $\begin{array}{l}\text { Larger product portfolio than its competitors, and that } \\
\text { results in competitive advantage. }\end{array}$ \\
\hline 29. & Paper & $\begin{array}{l}\text { Deink (ink abolish) facility that converts } \\
\text { scrap paper to raw materials }\end{array}$ & $\begin{array}{l}\text { Low-cost raw materials, Producing more competitive and } \\
\text { environmental products. }\end{array}$ \\
\hline 30. & $\begin{array}{l}\text { Glass } \\
\text { Households }\end{array}$ & $\begin{array}{l}\text { High technology in manufacturing, } \\
\text { Export to more than } 100 \text { countries, } \\
\text { New product development, and Wide } \\
\text { distribution channels }\end{array}$ & $\begin{array}{l}90 \% \text { market share via those competencies, Determining } \\
\text { price and other matters in the market. }\end{array}$ \\
\hline
\end{tabular}




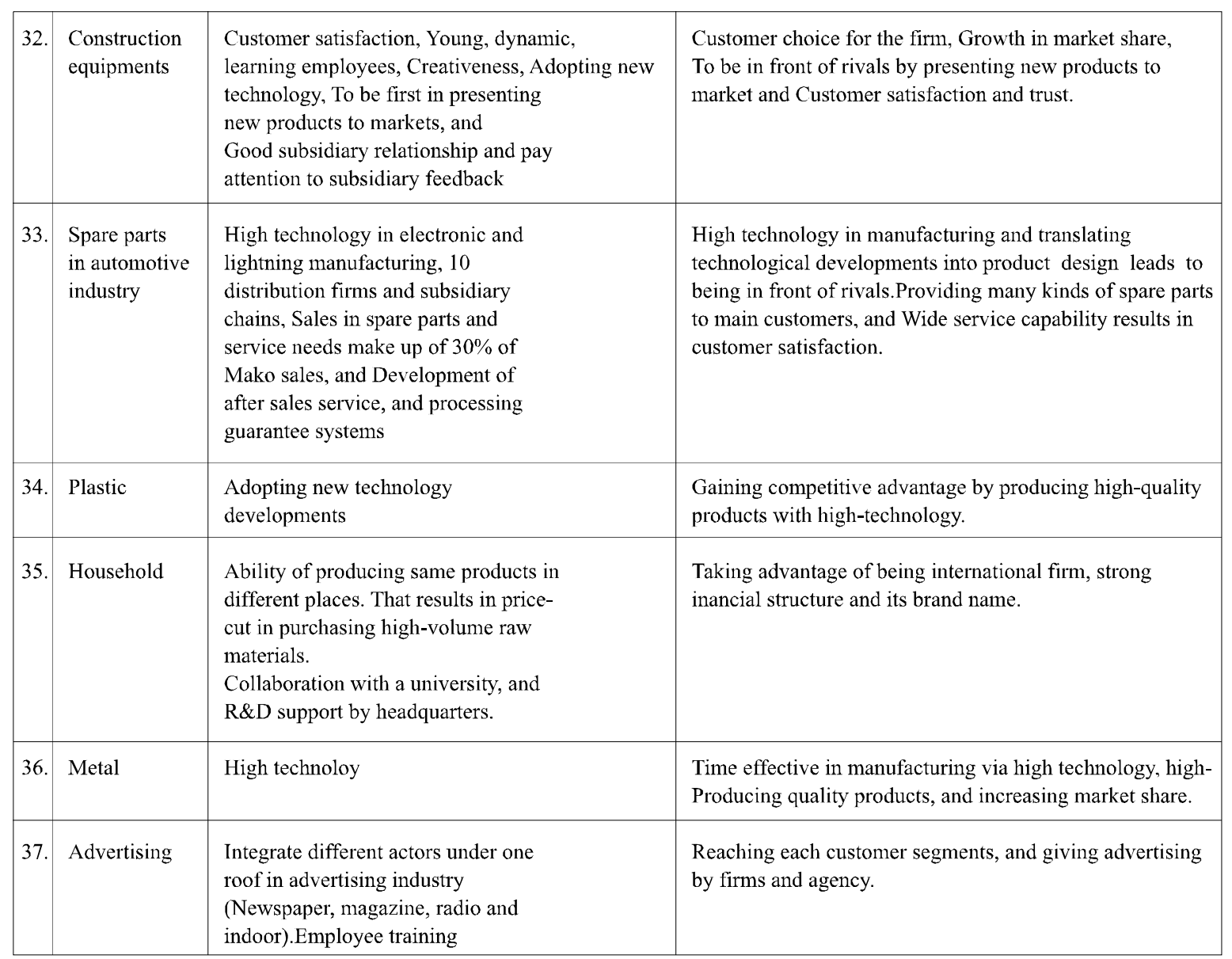

In order to effectively explain Table 1 above, we identify core competencies of Turkish firms that create differentiation, and state their impact on competitive advantage. For example, in textile industry, three firms have core competencies in production such as customer-oriented quality manufacturing, technology investment, $R \& D$, electronic and computer-aided manufacturing. The other firm says, their competencies are managerial activities, e.g., performance-based compensation, performance management, considering employee ideas. Another firm has competence in marketing such as in sales techniques. Employee experience and effective design team are core competencies of another firm. Therefore, a firm in textile industry is number one in manufacturing in Turkey, and number 7 in the world, and has competitive price, customer satisfaction and trust. The other one possesses time advantage in manufacturing, and faces high growth rate. Another firm has high demand for their products.

A construction company states, its competence is innovativeness. It provides the firm of being market leader in the industry. Hydrolic and number of hydrolic abkant press are core competencies of a machine manufacturing firm. The firm is number one in Turkish market. An agriculture machine company uses laser machines in manufacturing, and has R\&D lab. The firm is market leader in Turkey and number 10 in the world.

Core competence of a food company is hightechnology and fast manufacturing ability. The firm is number one in manufacturing capacity in Turkey. A stone and construction company possesses the highest technology, and environmental and health consciousness, and customer trust. The company has high market share and quality products. A tourism company has competence in continuous training, quality product and services with competitive price. The firm has first choice from international customers, and is number 3 in customer satisfaction.

An automotive company has core competencies in engine, sales force management, new product development, continuous development, regarding customer needs. Therefore, the firm can create strategic value, and gain market success. A machine products company has expertise, knowledge, product quality and design ability. Thus, the firm is industry leader, 
and can compete with world giants. Moreover, a pipe manufacturing company produces their products by their own technology. They take advantage of R\&D activities. That results in new market penetration, and having high technology that differentiate from rivals. A health company has high-technology health machines, and applies recent medical techniques, and possesses brand reputation in European market. The firm can shape the market in Turkey via its market leader position. A furniture company can do good market analysis, and has good forecasting ability, and high elasticity in their price policy. That results in being market leader and export leader in industry, shaping market, and having high company image.

A paper company has Deink (ink abolish) facility that converts scrap paper into raw materials. Therefore, the firm has low-cost raw materials. A glass household company possesses high technology in manufacturing that cuts production costs, and also has new product development, and wide distribution channels. Therefore, the firm has $90 \%$ market share, and can export more than 100 countries. A construction equipment company has young, dynamic and learningoriented employees, creativeness, and adopts new technology, and is the first in presenting new products to market, and has good subsidiary relationship, and good subsidiary feedback. Therefore, the firm has customer choice, growth in market share, and customer satisfaction and trust.

A spare parts manufacturing company in automotive industry has high technology in electronic and lightning manufacturing, and has 10 distribution firms and subsidiary chains, and has capability in developing after sales service, and in processing guarantee systems. High-technology in manufacturing and translating technological developments into product design leads to being in front of its rivals. The firm can provide many kinds of spare parts to main customers. Wide service capability results in customer satisfaction.

A plastic company adopts new technology developments. The firm gains competitive advantage by producing high-quality products via its hightechnology. A household company has ability in producing same products in different places. That results in price-cut in purchasing high-volume raw materials. The company collaborates with a university, and has R\&D support from headquarters in Berlin. The firm takes advantage of being international firm, strong financial structure, and brand reputation. A metal company has high technology. The firm is time effective in manufacturing via its high-technology, and can produce high-quality products, and thus, has customer choice, and increases market share. Finally, an advertising firm brings different actors under one roof in advertising industry such as newspaper, magazine, radio and indoor, and gives importance to employee training. Therefore, the firm can reach each customer segments, and has customer choice by firms and agency that plan giving advertising.

\section{CONCLUSION}

Thompson and Strickland (1995:115) highlight that if a company has an edge over rivals in attracting customers and defending against competitive forces, then it has a competitive advantage. Therefore, we can define competitive advantage as having competitive power in the market. Because a firm can attract customers by strong products that meet customer expectations that can be produced via core competence. Competence-based products create competitive edge by generating benefits and trust for customers. Thus, a customer pays product price that generates income for companies. Therefore, firms, at the beginning, should start with defining their core competencies to obtain competitive advantage via competence-based differentiation. However, firm's assets are not core competencies. For example, brand is not a core competence but brand management is a core competence. Similarly, financial power is not a competence but mobilization of finance is a core competence. If firms draw attention to this point, they can both define a number of core competencies and improve their current core competencies (K1r1m, 1998:44). Those results in developing strategies that creates differentiation in the eyes of customers. In addition, firms should identify future core competencies before their rivals do if they target having competitive advantage at future.

Furthermore, core competence of a firm provides of differentiating firm's product and services. Product features, attributes and characteristics that customers want can be put into products via core competence. Therefore, such products can meet customer needs. This is important matter because firms do business in highly competitive and dynamic business environment in which customer choice and customer satisfaction are key to gain competitive advantage. Customers satisfy with and choice a product if product involves their wants and demands. Thus, this increases firm's sales, market share and consequently, profit, i.e., increases firm's competitive advantage. Moreover, core competencies enhance quality of product that leads to high demand against product. All these result in positive word of mouth by customers, and increase firm's market reputation. Therefore, the firm becomes 
market leader in its industry that some firms declare in this study.

In order to create a competence-led strategy, it is firstly expected from executives to define their core competencies. Secondly, it is expected from them to find out whether their skills are truly superior, how sustainable the superiority is, how much value can the competence generate in comparison to other economic levers, and is the competence integral to their value proposition (Coney et. al., 1997:45-48)

The results of the study demonstrate that the majority of Turkish firms in this study identify their core competencies that differentiate from rivals in the market, and competitive advantage by core competence-based differentiation such as being market leader, high market share, customer choice, customer satisfaction and trust, and quality products, high demand for products. Furthermore, future research can be done in a bigger sample in Turkey, and in applying more comprehensive questionnaire instead of a few questions.

\section{REFERENCES}

Banerjee, P., (2003), Resource Dependence and Core Competence: Insights from Indian Software Firms, Technovation, 23, pp.251-263.

Carr, Chris, (1997), Competency-led Strategies Based on International Collaboration: Four Case Studies of Anglo-Japanese Cooperation, Knowledge and Process Management, 4, pp.49-62.

Clark, Delwyn N., (2000), Implementation Issues in Core Competence Strategy Making, Strategic Change, 9, pp.115-127.

Clark, D.N. and Scott, Dorian N., (2000), Core Competence Strategy Making and Scientific Research: The Case of HortResearch, New Zealand, Strategic Change, 9, pp.495-507.

Coyne, K.P., S.J.D. Hall and P.G. Clifford, (1997), Is Your Core Competence A Mirage?, The McKinsey Quartely,1, pp.40-55.

Douglas, T.J. and Ryman, Joel A., (2003), Understanding Competitive Advantage in The General Hospital Industry: Evaluating Strategic Competencies, Strategic Management Journal, 24, pp.333-347.

Dannels, Erwin, (2002), The Dynamics of Product Innovation and Firm Competences, Strategic Management Journal, 23, pp.1095-1121.

Franklin, Peter, (1997), Competitive Advantage and Core Competences, Strategic Change, 6, pp.371-375.

Gallon, M.R. and Stillman, Harold M., (1995), Putting Core Competency Thinking into Practice, Research Technology Management, 38, pp.20-32.

Godbout, Alain J., (2000), Managing Core Competencies: The Impact of Knowledge Management on Human Resources Practices in Leading-edge Organizations, Knowledge and Process Management, 7, pp.76-86.

Higgins, James M., (1996), Achieving the Core Competence It's as essay as $1,2,3, \ldots .47,48,49$, Business Horizons, March-April, 27-32.

Hitt, Micheal A., R. Duane Ireland and Robert E. Hoskisson, (1997), Strategic Management, West Publishing Company, St. Paul, MN. 
Kirım, A. (1998), Strategy and Management in the New World, Sistem Press, Istanbul.

King, A.W. and Zeithaml, Carl P., (2001), Competencies and Firm Performance: Examining the Causal Ambiguity Paradox, Strategic Management Journal, 22, pp.75-99.

Makadok, R. and Walker, Gordon, (2000), Identfying a Distinctive Competence: Forecasting Ability in the Money Fund Industry, Strategic Management Journal, 21, pp.853-864.

Mollersten, K. and Sandberg, Peter, (2004),

Collaborative Energy Partnerships in Relation to Development of Core Business Focus and Competence-A Study of Swedish Pulp and Paper Companies and Energy Service Companies, Business Strategy and the Environment, 13, pp.78-95.

Lei, D., Hitt, M.A. and Bettis, Richard, (1996), Dynamic Core Competences through Meta-Learning and Strategic Context, Journal of Management, 22, pp.549-569.

Osterlund, Jan, (2001), The Forgotten Revenue of Product Development: Learning New Competence, Systems Research and Behavioral Science, 18, pp.159170.

Pehrsson, Anders, (2004), Strategy Competence: A study of Successful Business Establishments, Strategic Change, 13, pp.271-282.

Porter, Michael E., (2000), Competitive Strategy, (Translated by Gülen Ulubilgin), Sistem Press, Istanbul.

Prahalad, C.K. and G. Hamel, (1990), The Core Competence of the Corporation, Harvard Business Review, May-June, pp.79-91

Stalk, G., P. Evans and L.E. Shulman, (2000), Competing on Capabilities, (Harvard Business Review on Corporate Strategy (Translated by Ahmet Gürsel), MESS Press Number: 327, June, pp.171-202.

Thompson, Arthur A., JR. and A. J. Strickland, (1995), Strategic Management, Richard D. Irwin, Inc., Chicago.

Torkkeli, M. and Tuominen, Markku, (2002), The Contribution of Technology Selection to Core Competencies, International Journal of Production Economics, 77, pp.271-284.
Williamson, Oliver E., (1999), Strategy Research: Governance and Competence Perspectives, Strategic Management Journal, 20, pp.1087-1108.

Wright, P.M., McMahan, G.C., McCormick, B. and Sherman, Scott W., (1998), Strategy, Core Competence, and HR Involvement as Determinants of HR Effectiveness and Refinery Performance, Human Resource Management, 1998, 37, pp.17-29. 